\title{
Research Notes: Conch Shell Cups and Black Drink
}

Jesse Todd

Unknown

Follow this and additional works at: https://scholarworks.sfasu.edu/ita

Part of the American Material Culture Commons, Archaeological Anthropology Commons, Environmental Studies Commons, Other American Studies Commons, Other Arts and Humanities Commons, Other History of Art, Architecture, and Archaeology Commons, and the United States History Commons

Tell us how this article helped you.

This Article is brought to you for free and open access by the Center for Regional Heritage Research at SFA ScholarWorks. It has been accepted for inclusion in Index of Texas Archaeology: Open Access Gray Literature from the Lone Star State by an authorized editor of SFA ScholarWorks. For more information, please contact cdsscholarworks@sfasu.edu. 


\section{Research Notes: Conch Shell Cups and Black Drink}

Creative Commons License

(c) $)$ (i) @

This work is licensed under a Creative Commons Attribution-NonCommercial 4.0 International License 


\title{
Research Notes
}

\section{Conch Shell Cups and Black Drink}

\author{
Jesse Todd
}

Dallas, Texas

Conch shell cups appear during Caddoan times as part of trade with other Mississippian groups. Approximately one thousand engraved conch shell cups and at least two to three thousand unengraved cups were found in the Great Mortuary at Spiro (Brown 1975:15). It is assumed that Black Drink (made from Ilex vomitoria) was drunk from the conch shell cups because two shell cups were found that contained possible tea residue (Milanich 1979:83). Adair (1968:22-23) relates how the Muskogee (Creeks) honored a wooden statue of an ancestral warrior by drinking tea from a conch shell cup. It appears there is some question that conch shell cups were used because Fairbanks (1979:132) states that both Adair's and Swanton's informants swore that the conch shell cups were held sacred by the Muskogee. Fairbanks adds that there is enough ethnographic as well as archeological evidence to associate conch shell drinking cups with the Black Drink Ceremony. What Fairbanks doesn't appear to do is to discuss the ethnographic evidence to support his contention. $\mathrm{He}$ is correct, however. William Bartram, in his discussion of the Black Drink Ceremony among the Creeks, states that two middle-aged men came in together at the door carrying large conch shells full of black drink and that the person who drank the tea from the shell must do so as long as the middle-aged person sings two notes for as long as the singer's breath could hold out (Van Doren 1928:358-359).

\section{References Cited}

Adair, James

1968 The History of the American Indians (original publication date 1775). Johnson Reprint, New York.

Brown, James

1975 Spiro Art and Its Mortuary Contexts. In: Death and the Afterlife in Pre-Columbian America, edited by Elizabeth P. Benson, pp. 1-32. Dumbarton Oaks Research Library and Collection, Washington DC.

Fairbanks, Charles H.

1979 The Function of Black Drink Among the Creeks. In: Black Drink: A 
Native American Tea, edited by Charles M. Hudson. University of Georgia Press, Athens.

Milanich, Jerald T. 1979 Origins and Distributions of Black Drink and the Ceremonial Shell Drinking Cup. In: Black Drink: A
Native American Tea, edited by Charles M. Hudson. University of Georgia Press, Athens.

Van Doren, Mark (editor) 1928 Travels of William Bartram (reprint edition). Dover Publications, New York. 